\title{
Methodological advances in imaging intravital axonal
}

\section{transport [version 1; peer review: 3 approved]}

\author{
James N. Sleigh (iD), Alessio Vagnoni (D)2,3, Alison E. Twelvetrees (D1, \\ Giampietro Schiavo (iD)
}

\footnotetext{
${ }^{1}$ Sobell Department of Motor Neuroscience and Movement Disorders, Institute of Neurology, University College London, London, UK

2Division of Cell Biology, MRC Laboratory of Molecular Biology, Cambridge, UK

${ }^{3}$ Department of Basic and Clinical Neuroscience, Maurice Wohl Clinical Neuroscience Institute, Institute of Psychiatry, Psychology and Neuroscience, King's College London, London, UK
}

V1 First published: 01 Mar 2017, 6(F1000 Faculty Rev):200 https://doi.org/10.12688/f1000research.10433.1

Latest published: 01 Mar 2017, 6(F1000 Faculty Rev):200

https://doi.org/10.12688/f1000research.10433.1

\section{Open Peer Review}

\begin{tabular}{rrr} 
Approval Status & \\
1 & 2 & 3 \\
\hline
\end{tabular}

\section{version 1}

01 Mar 2017

Faculty Reviews are review articles written by the prestigious Members of Faculty Opinions. The articles are commissioned and peer reviewed before publication to ensure that the final, published version is comprehensive and accessible. The reviewers who approved the final version are listed with their names and affiliations.

1. William C. Mobley, University of California, San Diego, La Jolla, USA

2. Michael Sendtner, University of Würzburg, Würzburg, Germany

3. Bettina Winckler, University of Virginia, Charlottesville, USA

Any comments on the article can be found at the end of the article. 
Corresponding authors: James N. Sleigh (j.sleigh@ucl.ac.uk), Giampietro Schiavo (giampietro.schiavo@ucl.ac.uk)

Competing interests: The authors declare that they have no competing interests.

Grant information: This work was supported by Wellcome Trust Sir Henry Wellcome Postdoctoral Fellowships (103191/A/13/Z to J.N.S. and 096141/Z/11/Z to A.E.T), a NC3Rs David Sainsbury Fellowship (NC/N001753/1 to A.V.), a Wellcome Trust Senior Investigator Award (107116/Z/15/Z to G.S.), and University College London (G.S.).

The funders had no role in study design, data collection and analysis, decision to publish, or preparation of the manuscript.

Copyright: ( 2017 Sleigh JN et al. This is an open access article distributed under the terms of the Creative Commons Attribution License , which permits unrestricted use, distribution, and reproduction in any medium, provided the original work is properly cited.

How to cite this article: Sleigh JN, Vagnoni A, Twelvetrees AE and Schiavo G. Methodological advances in imaging intravital axonal transport [version 1; peer review: 3 approved] F1000Research 2017, 6(F1000 Faculty Rev):200 https://doi.org/10.12688/f1000research.10433.1

First published: 01 Mar 2017, 6(F1000 Faculty Rev):200 https://doi.org/10.12688/f1000research.10433.1 
In vivo techniques are poised to provide novel insight into live axonal transport

Neurons are highly polarised, excitable cells with long, thin axons whose integrity requires specialised mechanisms to transport cargoes such as organelles (e.g. mitochondria) and molecules (e.g. proteins and RNA) in anterograde (from soma to axonal tips) and retrograde (from axonal tips to soma) directions ${ }^{1}$. This bi-directional axonal transport is governed by the kinesin and cytoplasmic dynein motor proteins, respectively, and is essential for neuronal survival and function ${ }^{2}$. Given the large distances over which these processes must occur, it is perhaps unsurprising that disturbances in axonal transport have been linked to both ageing and many severe nervous system diseases, including Alzheimer's disease $(\mathrm{AD})$ and amyotrophic lateral sclerosis $(\mathrm{ALS})^{3-5}$. Emphasising the importance of efficient axonal transport to nervous system health, mutations in a number of motor proteins have been identified as causative in neuronal disorders ${ }^{1,6,7}$.

Individual cargoes have long been tracked in real-time in primary neuron and ex vivo tissue axons ${ }^{8-10}$; however, there is evidence to suggest that these artificial environments do not consistently reflect the in vivo situation ${ }^{11-14}$. Differences in transport dynamics, such as average speeds and pause frequencies ${ }^{11}$, could be attributed to limitations inherent to these in vitro and ex vivo platforms. Cultured primary neurons lack the array of cells with which neurons normally physically and chemically interact in situ; for example, cultured motor neurons are not myelinated, do not contact target muscle cells, and lack a network of regulated excitatory and inhibitory input onto their cell bodies. Myelination ${ }^{15-17}$, target-derived signals ${ }^{18,19}$, and activity ${ }^{20-23}$ are all known to impact axonal transport, whereas non-cell autonomous and age-dependent disease mechanisms are difficult to accurately model in vitro. Mouse primary cultures are often derived from embryonic animals ${ }^{24,25}$ not currently analysed in vivo, which may also cause discrepancies, as could the current intrinsic variability of human induced pluripotent stem cell (hiPSC)derived neuronal cultures ${ }^{26}$. Furthermore, the artificially controlled in vitro environment could affect subcellular energy demands and transport kinetics ${ }^{27}$, as might stress caused by axotomy and the continual growth of primary cultures. Intravital analysis of axonal transport of individual cargoes (Figure 1) is therefore likely to provide more physiologically relevant insights into this dynamic process, albeit with its own pitfalls (Table 1) ${ }^{28-30}$.

In this short review, we will highlight recent methodological advances and adaptations enabling the in vivo imaging of axonal transport across model organisms, specifically focusing on techniques that track the fast axonal transport of individual cargoes in real-time rather than transport en masse. We will outline strengths and weaknesses of the methods along with findings they have generated (Box 1), highlight major outstanding questions (Box 2), and discuss possible improvements and future directions for in vivo analysis.

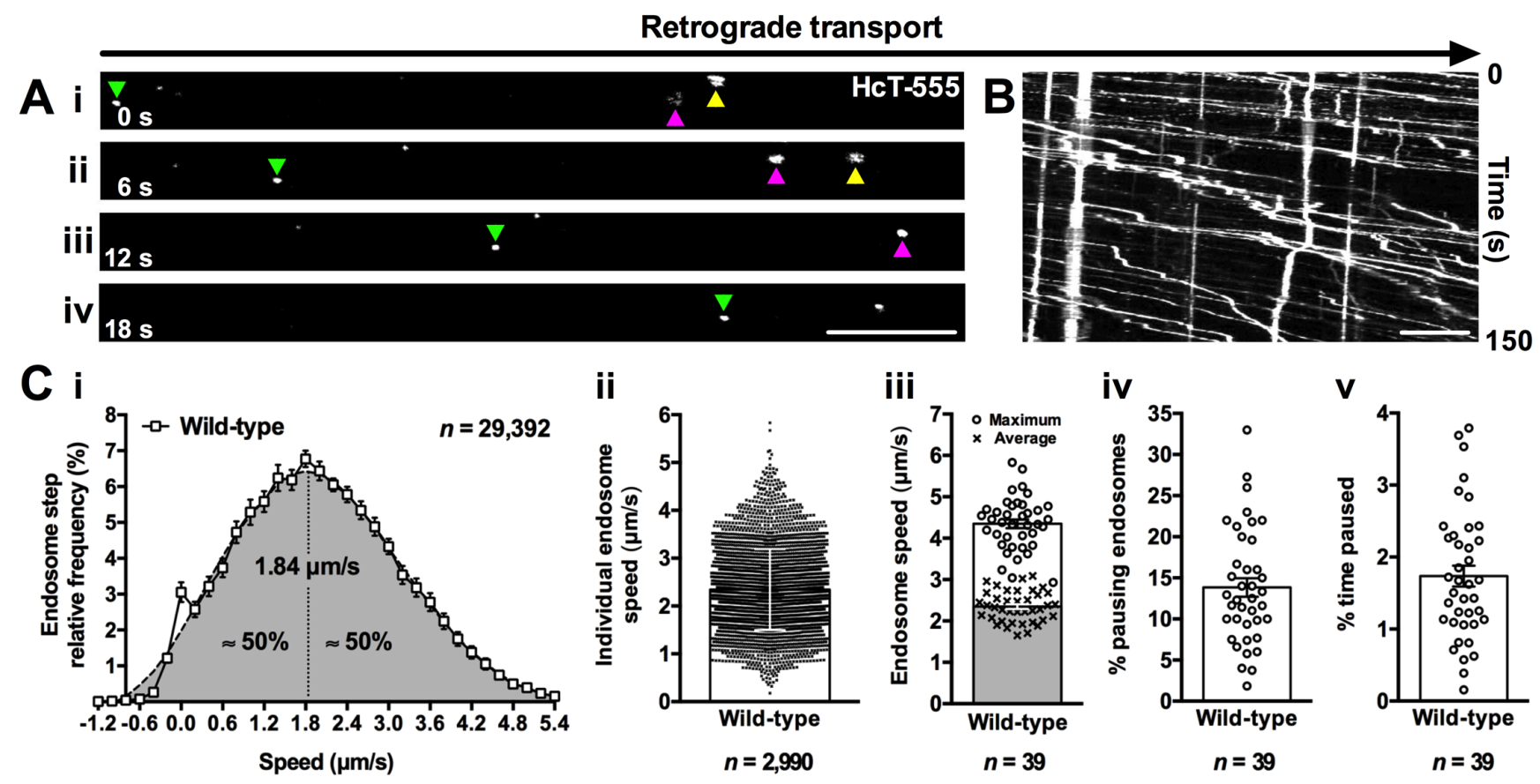

Figure 1. Imaging intravital axonal transport dynamics. (A) The transport of individual fluorescent cargoes along axons can be assessed in vivo. This series of time-lapse confocal microscopy images (i-iv) depicts the retrograde movement (left to right) of the tetanus toxin binding domain (HcT-555) in sciatic nerve axons, as detailed in Gibbs et al. ${ }^{11}$. Distinct signalling endosomes (e.g. coloured triangles) loaded with HcT-555 can be tracked across multiple images and transport assessed. (B) Representative kymograph generated from fluorescently labelled signalling endosomes being transported in sciatic nerve axons. (C) Numerous features of axonal transport kinetics can be assessed and plotted (see Box 3 also); for example, speed distribution curves of individual endosome steps (i), average endosome speeds (ii), mean endosome speeds per animal (iii), the percentage of endosomes that remain stationary for at least two consecutive frames (iv), and the percentage of time spent pausing $(\mathrm{v})$. The data reported here were generated from 39 wild-type (C57BL/6) animals aged from 1 to over 13 months, which is a period when transport dynamics are known to remain stable ${ }^{71}$. Scale bars $(A-B)=10 \mu m$. 
Table 1. The benefits and pitfalls of in vivo imaging of axonal transport compared with in vitro and ex vivo platforms.

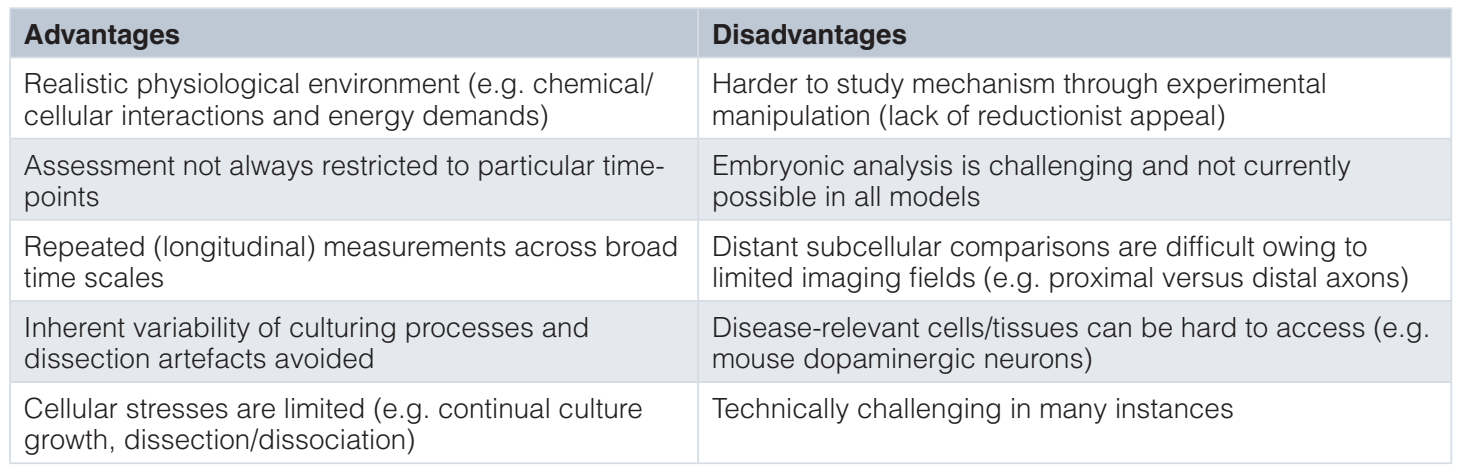

\section{Transport of diverse cargoes can be assessed in Drosophila wing sensory neurons over the lifespan of the animal}

The sophisticated genetic toolboxes of Caenorhabditis elegans and Drosophila melanogaster allow the specific targeting of fluorescent proteins to vesicles and organelles such as mitochondria. When coupled with the ever-expanding repertoire of neurological disease-relevant worm and fly models ${ }^{31-34}$, these reporter lines provide a powerful system for analysing the axonal transport of assorted cargoes in both ageing and disease ${ }^{35-40}$. Transport studies in Drosophila have largely been performed in filleted larval preparations rather than adult flies, limiting the time period over which analyses can be performed and the developmental stage of the neurons under investigation. Third instar larvae are typically dissected for imaging of fluorescent cargoes predominantly in motor axons ${ }^{41,42}$. Alternatively, microfluidic devices that physically immobilise intact Drosophila larvae afford a non-invasive approach to image axonal transport ${ }^{43,44}$.

A novel technique to analyse transport dynamics in sensory axons of the Drosophila wing has been developed (Figure 2A), which permits the assessment of axonal trafficking throughout the lifespan of adult flies ${ }^{45,46}$. The marginal nerve found on the anterior edge of fly wings consists of chemosensory and mechanosensory neurons ${ }^{47,48}$, the cell bodies of which are connected by short dendrites to wing bristles, while their axons bundle together and project to the central nervous system $(\mathrm{CNS})^{45}$. Given the translucency of the wing and the accessibility of the marginal nerve, rapid and non-invasive light microscopy can be performed on different wing regions of flies expressing fluorescently tagged proteins specifically in neurons. Motivated by previous work in which the same nerve was used to evaluate in vivo responses to neuronal injury ${ }^{49,50}$, the GAL4-UAS system was implemented to visualise mitochondria and dense core vesicle (DCV) transport dynamics in flies up to 30 days old (their natural lifespan being $\approx 50$ days in the laboratory $)^{45}$. Flies showed an early peak in the number of bi-directional moving mitochondria during early adulthood and subsequent decline with age linked to misfolded axonal protein accumulations; however, the dynamic properties of the moving mitochondria did not change with time.
Intriguingly, reduced levels of the dynein co-factor Lissencephaly1 (Lis1) caused a doubling in the number of motile mitochondria across time-points (without increasing their number) and reduced the age-associated build-up of protein in the axon ${ }^{45}$. Contrasting with mitochondria, the percentage of motile DCVs remained steady across ages in wild-type flies and was unaffected by reduced Lis1 levels, which is indicative of an organelle-specific perturbation rather than a global transport defect. Although the Drosophila marginal nerve cannot be used for whole-mount staining or large-scale biochemistry and has no direct counterpart in humans, its simple preparation permits quick and non-invasive analysis of anterograde and retrograde axonal transport in sensory nerves of adult flies. Without constraints on fly age, extended experimental time-points can be incorporated, facilitating the study of ageing and neurodegeneration in Drosophila.

\section{Assessment of cargo motility in axons from an array of zebrafish neuronal subtypes}

As a genetic model, the zebrafish (Danio rerio) possesses many of the advantages of the invertebrate species, such as short generation time and lower maintenance costs, with the added benefit of being a vertebrate with myelinated axon tracts ${ }^{51}$. Also, like worms and flies, zebrafish are highly genetically tractable, with an array of reporter lines expressing fluorescently tagged proteins in specified organelles in subsets of cells. Zebrafish larvae are translucent, which obviates the need for invasive imaging techniques and allows repeated, longitudinal in vivo measurements throughout development. Several studies have probed cargo movement in the axons of anaesthetised zebrafish, the first of which assessed mitochondrial dynamics in sensory nerves called Rohon-Beard (RB) neurons found in the tail tip ${ }^{52}$. These transgenic "MitoFish" were created using the GAL4-UAS system to specifically express fluorescent proteins in the mitochondria of single RB neurons. A number of other groups have created similar fluorescent fish to assess the dynamics of RB mitochondria ${ }^{53}$ and endosomes ${ }^{54,55}$, as well as lysosomes in mechanosensory axons ${ }^{56,57}$.

Until recently, the bulk of in vivo zebrafish transport analysis was conducted in sensory nerves; however, a number of groups have 


\section{Box 1. Recent major insights into axonal transport provided by in vivo imaging}

- Consistent with sciatic nerve explant data ${ }^{5}$, the percentage of motile mitochondria in the Drosophila marginal nerve declines with age, while the dynamic properties (run speed and length) remain unchanged

- $\quad$ Reduced levels of the dynein co-factor Lissencephaly-1 caused an increase in the percentage of motile mitochondria in the Drosophila marginal nerve ${ }^{45}$

- Defective mitochondrial transport results in an increase of protein aggregation in Drosophila neurons; conversely, upregulating mitochondrial transport correlates with a delayed appearance of protein aggregates ${ }^{45}$

- In zebrafish retinal ganglion cells (RGCs), disruption of Kif5A, a neuron-specific anterograde motor, resulted in increased frequency of retrograde mitochondrial transport but not synaptophysin-containing vesicles ${ }^{58}$

- Zebrafish models of Charcot-Marie-Tooth disease type $2 \mathrm{~A}^{59}$ and Parkinson's disease ${ }^{60}$ showed mitochondrial motility defects in disease-relevant nerve cells

- During larval development (2-5 days post-fertilisation), the percentage motility of mitochondria and the ratio of anterograde to retrograde movements progressively decreased in zebrafish central nervous system (CNS) dopaminergic neurons, whereas run length increased, but speeds remained stable ${ }^{60}$

- Amyotrophic lateral sclerosis (ALS) mice, but not spinal and bulbar muscular atrophy mice ${ }^{70}$, display pre-symptomatic defects in the transport speeds of signalling endosomes in sciatic nerve axons ${ }^{67}$; mitochondrial transport is also perturbed in both SOD and TDP-43 models of ALS 67,68

- Retrograde axonal transport kinetics (speed, \% pausing, and \% time paused) of signalling endosomes in the sciatic nerve remain unchanged from 1 to over 13 months ${ }^{71}$, which varies from the age-related transport deficiencies reported in different experimental settings at similar time points ${ }^{12,89,90}$

- Bi-directional defects in the transport of both mitochondria and peroxisomes are detected in spinal cord axons of acute and chronic multiple sclerosis mouse models before major symptom onset ${ }^{77}$

- In mouse RGCs, the number of moving mitochondria, but not run length, was decreased prior to cell death in a glaucoma model, whereas the duration and distance of mitochondrial transport were both diminished with age (23-25 months) ${ }^{12}$

- The vast majority of mitochondria in neonatal and adult cortical pyramidal neurons remain stationary over periods of up to 20 minutes $^{13,14}$

\section{Box 2. Outstanding questions that will benefit from} advances in intravital imaging

- What is the direct biological significance of altered cargo pausing and transport speeds?

- $\quad$ Are the defects in axonal transport observed in myriad neurological disease a cause of neuronal dysfunction or the consequences of a dysfunctional neuron?

o Will therapeutics targeting axonal transport ameliorate symptoms of these diseases?

- Does ageing impact all neuronal and cargo subtypes equally?

- What mechanisms underlie cargo-specific disturbances in transport versus global transport deficiencies?

- Why do mutations in mitochondrial ${ }^{91}$ and motor proteins often manifest in a nervous system-specific pathology?

- Why are neurons particularly vulnerable to trafficking defects?

- What causes the axonal transport of distinct cargoes to be differentially affected by ageing and diseaseassociated mutations?

capitalised on the translucency and genetics of the fish and expanded the arsenal of neuronal types amenable to imaging. To assess the visual system, transgenic fish expressing fluorescent protein in either the synaptic vesicles or the mitochondria of retinal ganglion cells (RGCs) were created $^{58}$. Disruption of the neuron-specific anterograde motor Kif5A increased the number of small motile synaptophysin-containing vesicles at early developmental stages without altering the ratio of anterograde to retrograde transport. In contrast, the percentage of mobile mitochondria was unaffected in Kif $^{-1-}$ animals, but mitochondria were transported more frequently in the retrograde direction, which likely causes the observed depletion of axonal mitochondria. Similar to the above Drosophila study ${ }^{45}$, these experiments once again highlight that transport of distinct organelles can be differentially impacted depending on the type and stoichiometry of the motor proteins driving their movement. The results also emphasise the importance of measuring multiple transport parameters (Box 3), as different conclusions would have been reported if just the percentage of motile mitochondria was assessed. In addition to RGCs, new transgenic lines have been generated to assess mitochondrial dynamics in middle primary (MiP) motor neurons of the spinal cord ${ }^{59}$ and CNS dopaminergic neurons ${ }^{60}$ (Figure 2B). These fish were used to show that models of Charcot-Marie-Tooth disease type 2A (CMT2A) ${ }^{59}$ and Parkinson's disease $(\mathrm{PD})^{60}$ display perturbations in mitochondrial motility in 
A

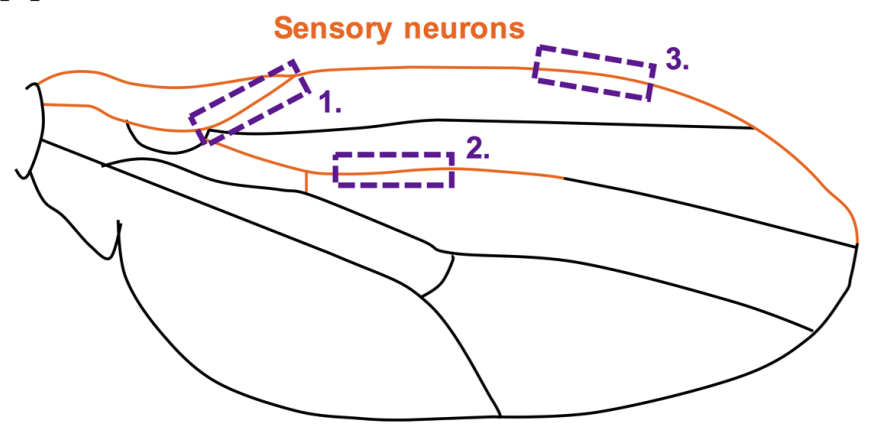

B

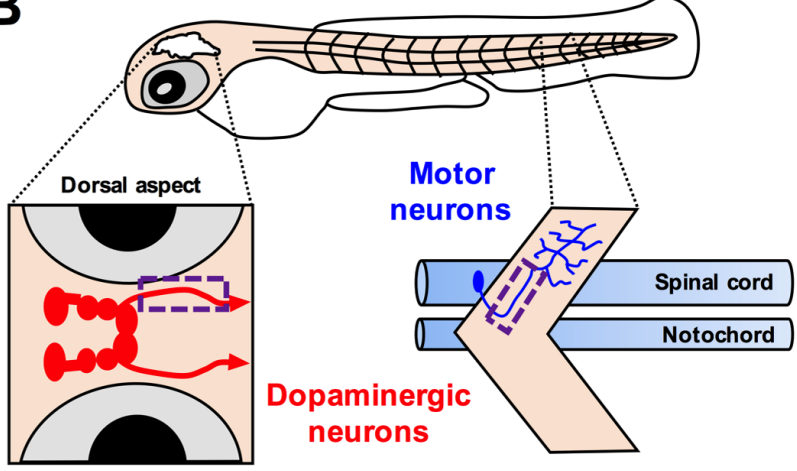

C i

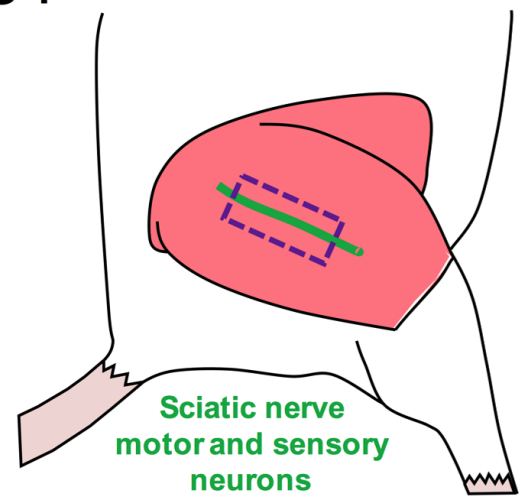

ii

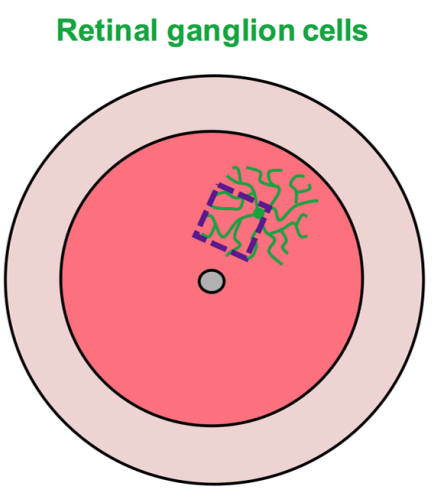

iii

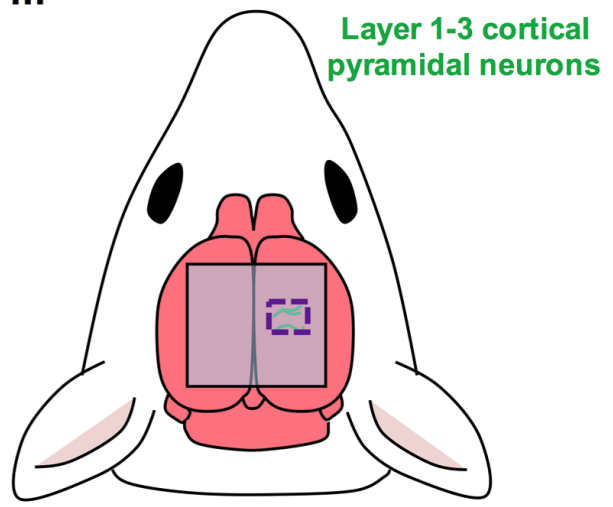

Figure 2. Developments in intravital imaging of axonal transport. (A-C) Recent technical advances have permitted the assessment of axonal cargo dynamics in a range of neuron types across different live model organisms. In the past few years, organelles have been tracked for the first time in sensory neurons of the adult Drosophila wing (orange, A) $)^{45,46}$ and larval zebrafish retinal ganglion cells ${ }^{58}$, central nervous system (CNS) dopaminergic neurons (red, B), and middle primary (MiP) motor neurons (blue, B) ${ }^{59,60}$. In the mouse, a more experimentally challenging animal model because of its non-translucency, in vivo transport was assessed in (i) motor and sensory sciatic nerves ${ }^{11,68,71,72}$, axons of the spinal cord and dorsal roots ${ }^{77}$, (ii) retinal ganglion cells ${ }^{12}$, and (iii) distal layer $1-3$ cortical pyramidal neurons ${ }^{13,14}$ (C). The purple, dashed-line boxes indicate approximate imaging regions.

disease-relevant neuronal subtypes; CMT2A motor nerves had a reduced percentage of motile mitochondria with unchanged speeds, while PD dopaminergic neurons displayed multiple transport defects dependent on the dose of toxin $\left(\mathrm{MPP}^{+}\right)$used to model the disease. The percentage of motile mitochondria and the ratio of anterograde to retrograde movements decreased during larval development (2-5 days post-fertilisation) in wild-type dopaminergic neurons, while speeds remained stable and run lengths increased ${ }^{60}$. Given the assortment of neurons now available for imaging, zebrafish provide an exciting platform for the in vivo analysis of axonal transport during development, with the caveat that once zebrafish reach adulthood, they become opaque, abrogating their utility for post-larval analyses.

\section{Peripheral and central nerve transport dynamics can both be assessed in mice}

Intravital imaging techniques have been developed in mice to study a range of biological processes in vivo, including the response to spinal cord injury ${ }^{61}$, retinal degeneration ${ }^{62}$, and cortical function and development $t^{63,64}$. Similar to the animal models mentioned above, experimentalists working with mice can use an extended library of transgenic fluorescent reporter strains facilitating live imaging ${ }^{28,65}$. Consequently, there has been a recent flurry of publications adapting these in vivo techniques for the analysis of axonal transport in live mice.

Among these, transgenic mice selectively expressing fluorescent proteins in neuronal mitochondria called "MitoMice" were generated by the Lichtman laboratory in $2007^{66}$. Mitochondria are labelled throughout most of the "MitoMouse" nervous system, permitting in vivo analysis across a broad spectrum of neuronal subtypes provided they can be accessed in live animals. In this publication, in vivo axonal transport of individual organelles was imaged for the first time in a live mammal ${ }^{66}$. Mitochondrial kinetics were analysed in single motor and sensory axons of surgically exposed sciatic nerves using time-lapse confocal microscopy (Figure 2Ci).

Adaptations of this technique have since been developed and expounded upon by a number of different laboratories. The Schiavo group crossed the "MitoMouse" with the SOD1 ${ }^{\mathrm{G} 93 \mathrm{~A}}$ mouse model of ALS and showed that mitochondrial transport speeds are pre-symptomatically impaired in sciatic nerve axons, which is one 


\section{Box 3. Axonal transport analysis}

A multitude of subtly different and sometimes co-dependent axonal transport parameters may be measured. Some features, such as the ratio of anterograde to retrograde movements, cannot be assessed for certain cargoes, e.g. signalling endosomes, which are transported only from the periphery to the cell soma. Cargo type should thus be considered and the aims of each individual experiment carefully determined before selecting from the following analysis options, which may also be subdivided into anterograde, retrograde, bi-directional, and combined categories:

- Speed

- Frequency of frame-to-frame speeds (Figure 1Ci) $)^{11,67,70,71}$

- Individual cargo average velocities (Figure 1Cii)

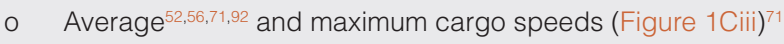

- Immobile cargoes can be either included or omitted, and analysed separately ${ }^{59}$, while movement-only speeds (i.e. uninterrupted runs or constant-velocity segments) can be determined ${ }^{52,92}$

\section{- Motility}

- Percentage $\mathrm{e}^{14,35,45}$ and number $20,52,56,92$ of motile cargoes in a given time (also called flux)

o Percentage of time motile cargoes are moving ${ }^{12,60}$

- $\quad$ Average $^{56}$ and longest ${ }^{45}$ run distances (run length)

o Run duration ${ }^{12,13,39}$

\section{- Pausing}

- Percentage of cargoes that pause (Figure 1Civ) $)^{67,71}$

o Percentage ${ }^{21,71}$ and length ${ }^{52,77,92}$ of time that motile cargoes remain stationary (Figure $1 \mathrm{CV}$ )

- Pause frequency ${ }^{52,92}$

- Percentage ${ }^{13,58}$ and number ${ }^{20}$ of cargoes that remain stationary

\section{- Anterograde, retrograde, and bi-directional}

o Ratio of anterograde to retrograde movements ${ }^{58} /$ net direction of transport ${ }^{35}$

- Percentage of time spent anterogradely moving/stationary/retrogradely moving ${ }^{36}$

- Frequency and percentage of cargoes that show reversals in transport direction ${ }^{35}$

o Percentage of cargoes that oscillate ${ }^{36}$ or remain uni-directional ${ }^{60}$

Microscope settings can also impact axonal transport results, so care must be taken when making cross-study comparisons. Furthermore, whether recordings will be manually or automatically tracked must also be taken into account. The following should therefore be contemplated:

- Frame rate: there is always a trade-off between sampling frequency and specimen integrity ${ }^{93,94}$. For example, a low-frequency frame rate (less than $1 \mathrm{~Hz}$ ) could miss brief pauses, resulting in the recording of slower "moving" speeds for individual cargoes and fewer pauses. Rapid frame rates may provide more accurate information but must be offset against how rapidly a sample bleaches, potential phototoxic changes to specimen physiology, and the signal-to-noise ratio. Frame rate also directly impacts the labour required for analysis if manual tracking of cargoes is carried out.

- Imaging time: the longer an axon is imaged, the greater the chance that stationary organelles, particularly mitochondria, will become motile. The impact of phototoxicity should also be considered. Imaging over several orders of magnitude can circumvent this problem: for example, imaging at $2 \mathrm{~Hz}$ for 1 minute followed by $0.2 \mathrm{~Hz}$ for 10 minutes ${ }^{95}$.

of the first observable deficiencies in this disease model ${ }^{67}$. Another laboratory confirmed this result and expanded it to the TDP-43 $3^{\mathrm{A} 315 \mathrm{~T}}$ mouse model of ALS ${ }^{68}$. Using a fluorescently tagged atoxic binding fragment of tetanus neurotoxin $\left(\mathrm{H}_{\mathrm{C}} \mathrm{T}\right)$, the dynamics of a second type of organelle, the signalling endosome, were assessed in the sciatic nerve of SOD1 ${ }^{\mathrm{G} 93 \mathrm{~A}}$ mice (Figure 1$)^{67}$. Fluorescent $\mathrm{H}_{\mathrm{C}} \mathrm{T}$ was injected under anaesthesia into the gastrocnemius and tibialis anterior muscles of the lower leg, where it binds to nidogen receptor proteins of the basement membrane before internalisation at the neuromuscular junction ${ }^{69}$. Once in the nerve terminal, the toxin hijacks the retrogradely transported signalling endosomes, which can be tracked in sciatic nerve axons in vivo ${ }^{11}$. Signalling endosome movement was also shown to be impaired ${ }^{67}$, suggestive of a generalised transport defect in SOD mutant mice. This is most likely caused by global changes in general transport machinery, e.g. the microtubule network, as opposed to disruption of multiple cargospecific pathways. Confirming that defective retrograde transport of signalling endosomes is not a general read out of an impaired or aged nervous system, in separate studies spinal and bulbar muscular atrophy mice ${ }^{70}$ and wild-type animals aged to over 13 months $^{71}$ were both shown to have normal endosome transport dynamics. A minor drawback of these studies is that the identity of sciatic nerve motor and sensory axons cannot be readily differentiated. Nonetheless, there is the possibility of injecting $\mathrm{H}_{\mathrm{C}} \mathrm{T}$ into the footpad to 
target nociceptive sensory neurons or injecting a fluorescently labelled $\mathrm{p} 75^{\mathrm{NTR}}$ neurotrophin antibody into muscle, which is mainly taken up by sensory nerves ${ }^{11,67}$. Moreover, crossing of disease models with transgenic mice selectively expressing fluorescent proteins in motor axons (e.g. using the Hb9/Mnx1 promoter) could also help to overcome this issue. Alternatively, the mainly motor femoral nerve ${ }^{72}$ or primarily sensory sural ${ }^{72}$ or saphenous nerves ${ }^{20}$ could be imaged either in fluorescent reporter strains or by altering the $\mathrm{H}_{\mathrm{C}} \mathrm{T}$ injection site to ensure fluorescent signalling endosome transport in the appropriate nerve. However, these alternative peripheral nerves are more technically challenging to image on an inverted microscope because of their anatomical distribution and size. Indeed, the sciatic nerve is a large, superficial collection of peripheral nerve axons, in which the dynamics of various cargoes can be imaged, with the useful possibility for longitudinal analysis in the same animal ${ }^{66,72}$

In contrast, the mouse CNS is inherently more difficult than the relatively accessible peripheral nervous system to image directly; nevertheless, axonal transport has now been successfully tracked in a number of CNS neurons. Axons within the spinal cord can be surgically exposed by dorsal laminectomy and imaged across time and several spinal segments in vivo ${ }^{61,73-75}$, permitting longitudinal and location-specific comparisons. Mice expressing fluorescent proteins in only a small percentage of sensory neurons have been used to assess axonal degeneration caused by spinal cord lesion in individual large, myelinated sensory axons found in the dorsal aspect of the spinal cord ${ }^{61}$. Numerous synthetic vital dyes that label structures such as myelin and microglia can also be used to aid in vivo analysis of the spinal cord ${ }^{76}$. This technique was recently implemented to assess axonal transport in acute and chronic mouse models of multiple sclerosis (MS $)^{77}$. Crossing these strains with "MitoMice" and specifically generated "Thy1-PeroxiYFP" mice, both mitochondria and peroxisomes, respectively, were imaged in spinal cord and dorsal root axons. Pervasive defects in anterograde and retrograde transport of both cargo types were observed in MS mouse spinal cord axons before the onset of additional deficiencies, suggesting that axonal transport defects represent an early and important pathological sign in this disease ${ }^{77}$. These defects were not seen in dorsal root axons (sensory nerves), suggesting that subcellular location (i.e. proximity to the soma) has a bearing on axonal transport defects. However, the sensory identity of the axons imaged in the spinal cord was only presumed (owing to their dorsal location) and not experimentally confirmed, so the potential sitespecific transport issue could instead be a product of neuron subtype (e.g. motor versus sensory).

Multi-photon microscopy has also been used to assess mitochondrial transport dynamics in the axons of RGCs of anaesthetised "MitoMice" (Figure 2Cii) ${ }^{12}$. RGC axons extend into the nerve fibre layer of the eye, parallel to the ocular surface of the sclera, permitting the visualisation of organelles after subtle opening of the surrounding skin and conjunctiva. The number of moving mitochondria, but not their run length, was diminished before RGC death in a model of glaucoma, whereas in aged mice (23-25 months), the duration and distance of mitochondrial movement were both diminished ${ }^{12}$. Interestingly, counter to results from retinal explants in the same study, this method showed that mitochondrial transport is highly dynamic in the mouse CNS in vivo ${ }^{12}$. Unfortunately, as fluorescence microscopy could impact the activity of light-sensitive retinal neurons, this observation may be confounded by artefactual alterations in mitochondrial dynamics (i.e. caused by increased activity ${ }^{20}$ ). Furthermore, this technique is restricted to albino strains because uveal pigmentation prevents imaging, and is more technically challenging with gaseous anaesthetics because of face access requirement. Nonetheless, in vivo comparisons of organelle transport in proximal and distal regions of RGC axons allow for repeated, longitudinal analyses.

Finally, a technique developed to image distal layer 1-3 pyramidal neurons of the cortex has been independently adapted by two groups to assess axonal transport through a surgically fitted cranial window in both anaesthetised and awake mice (Figure 2Ciii) ${ }^{13,14}$. Rather than using transgenic fluorescent strains, plasmids were unilaterally electroporated into embryos in utero to target the expression of fluorescent proteins to both the mitochondria and the cytoplasm ${ }^{13}$ or membranes ${ }^{14}$ of cortical progenitor cells (the latter to aid the identification of successfully transfected neurons). The process of electroporation restricts the fluorescence to a small proportion of axons, facilitating the assessment of individual collaterals. Similar to previous in vivo reports from zebrafish RB sensory ${ }^{52}$ and CNS dopaminergic $^{60}$ neurons and mouse sciatic nerve axons ${ }^{66}$, the percentage of immobile mitochondria in cortical axons was very high over short time periods: $>99 \%$ in 2 minutes in both pups (P10-13) and adults $(\mathrm{P} 70-120)^{14}$ and $\approx 90 \%$ at P10-12 over $10-20$ minutes $^{13}$. The discrepancy between these two studies could reflect the different but overlapping cortical layers that were imaged; however, it is more likely caused by the 5 - to 10 -fold difference in imaging periods. Indeed, over $95 \%$ of mitochondria were reported as stationary in mature cortical neurons in culture when imaged for 30 minutes, which drops to $\approx 75 \%$ using a 12 -hour imaging window $^{13}$. This highlights a key problem in the study of axonal transport: to track individual cargo movements, rapid frame rates are required, but biologically relevant transport events may occur separated by much longer periods (minutes to hours), which is particularly challenging for in vivo imaging (Box 3). Thus, although surgically intensive and technically demanding, this method of imaging cortical collaterals allows repeated, longitudinal analyses of CNS neurons of the brain in live, non-anaesthetised mice.

\section{Concluding remarks}

The active transport of organelles and molecules along axons is critical to neuronal health, function, and survival. Deficiencies in this process appear to be intricately linked to ageing and neurodegeneration, but whether they play a causal role or are simply a consequence of a pathologically affected tissue remains to be fully elucidated in each setting (Box 2). There are numerous possibly conflicting data reported on the dynamics of axonal cargoes. These differences could be due to several reasons, including experimental setting and parameters, neuronal subtype, cargo type, time-point, axonal location (i.e. distal versus proximal ${ }^{78}$ ), and neuronal morphology (e.g. proximity to axonal arbor branches ${ }^{52}$ ). With recent developments discussed here, we are beginning to acquire a diverse and very powerful arsenal of in vivo experimental systems across model organisms that will greatly enrich our understanding of transport. It is now vital to implement these intravital methods to 
tackle the questions of when (age), where (neuron category and subcellular location), what (cargo type), and how axonal transport deficiencies manifest in neuronal dysfunction.

Progress in imaging axonal transport in vivo has challenges in common with all in vivo imaging experiments (e.g. limited transparency of tissue, restricted imaging depth, and phototoxicity) as well as formidable problems unique to the phenomena being studied: namely, relevant scales of measurement that span several orders of magnitude, both in time and distance. The difficulty in labelling cargoes specifically and with a labelling density allowing a sufficient signal-to-noise ratio for transport analysis is highlighted by the small number of axonal cargoes currently being studied, which are almost exclusively membranous organelles. Using bright, photoactivatable fluorophores is a particularly helpful strategy for studying transport, as it allows the tracking of subpopulations of cargo otherwise too dense to study individually or sparse cargoes over long time periods ${ }^{13}$. However, there is an urgent need to adopt new labelling strategies and fluorescent reporters to understand the behaviour of non-membrane-bound organelles, particularly in the field of RNA transport. Much of what has been learnt about organelle transport is garnered from experiments on mitochondria ${ }^{30}$; however, their movement within axons, which is characteristically interspersed by long pauses and thus perhaps more characteristic of slow axonal transport, is not reflective of all cargo types. This is perhaps because they have distinct axonal roles, rely on specific subsets of adaptor and motor proteins ${ }^{2}$, and are unique, highly dynamic, network-forming organelles. To have a thorough and informed understanding of axonal transport in health and disease, it is therefore of paramount importance that multiple cargo types are analysed.
Most of the methods discussed here are adaptations of intravital techniques initially developed to study other biological processes. It is therefore likely that imaging of additional neuronal subtypes or subcellular locations ${ }^{79-86}$ could be incorporated into these analyses in order to provide a more global assessment of in vivo axonal transport in health and disease. Moreover, as imaging techniques become more sophisticated, allowing high-speed, multi-channel acquisition at greater tissue depths ${ }^{87,88}$, we will be able to simultaneously monitor the dynamics of different organelles in their native environment and reliably assess the transport of organelles, such as RNA granules, for which similar robust protocols are currently lacking.

\section{Competing interests}

The authors declare that they have no competing interests.

\section{Grant information}

This work was supported by Wellcome Trust Sir Henry Wellcome Postdoctoral Fellowships (103191/A/13/Z to J.N.S. and 096141/ Z/11/Z to A.E.T), a NC3Rs David Sainsbury Fellowship (NC/ N001753/1 to A.V.), a Wellcome Trust Senior Investigator Award (107116/Z/15/Z to G.S.), and University College London (G.S.).

The funders had no role in study design, data collection and analysis, decision to publish, or preparation of the manuscript.

\section{Acknowledgements}

The authors would like to thank members of the Schiavo and Linda Greensmith (Institute of Neurology, UCL) laboratories for productive discussions.
1. Maday S, Twelvetrees AE, Moughamian AJ, et al:: Axonal transport: cargo-specific mechanisms of motility and regulation. Neuron. 2014; 84(2): 292-309.

PubMed Abstract | Publisher Full Text | Free Full Text

2. Hirokawa N, Niwa S, Tanaka Y: Molecular motors in neurons: transport mechanisms and roles in brain function, development, and disease. Neuron. 2010; 68(4): 610-38.

PubMed Abstract | Publisher Full Text

3. Millecamps S, Julien JP: Axonal transport deficits and neurodegenerative diseases. Nat Rev Neurosci. 2013; 14(3): 161-76.

PubMed Abstract | Publisher Full Text

4. Adalbert R, Coleman MP: Review: Axon pathology in age-related neurodegenerative disorders. Neuropathol Appl Neurobiol. 2013; 39(2): 90-108. PubMed Abstract | Publisher Full Text

5. Milde S, Adalbert R, Elaman MH, et al:: Axonal transport declines with age in two distinct phases separated by a period of relative stability. Neurobiol Aging. 2015; 36(2): 971-81.

PubMed Abstract | Publisher Full Text | Free Full Text

6. Schiavo G, Greensmith L, Hafezparast M, et al.: Cytoplasmic dynein heavy chain: the servant of many masters. Trends Neurosci. 2013; 36(11): 641-51. PubMed Abstract | Publisher Full Text | Free Full Text

7. Lipka J, Kuijpers M, Jaworski J, et al:: Mutations in cytoplasmic dynein and its regulators cause malformations of cortical development and neurodegenerative diseases. Biochem Soc Trans. 2013; 41(6): 1605-12. PubMed Abstract | Publisher Full Text

8. F Lalli G, Schiavo G: Analysis of retrograde transport in motor neurons reveals common endocytic carriers for tetanus toxin and neurotrophin receptor p75 ${ }^{\mathrm{NTR}}$. J Cell Biol. 2002; 156(2): 233-9.

PubMed Abstract | Publisher Full Text | Free Full Text | F1000 Recommendation
9. Terry AV Jr, Stone JD, Buccafusco JJ, et al:: Repeated exposures to subthreshold doses of chlorpyrifos in rats: hippocampal damage, impaired axonal transport, and deficits in spatial learning. J Pharmacol Exp Ther. 2003; axonal transport $375-84$.

PubMed Abstract | Publisher Full Text

10. Stone JD, Peterson AP. Eyer J, et al: Axonal neurofilaments are nonessential elements of toxicant-induced reductions in fast axonal transport: videoenhanced differential interference microscopy in peripheral nervous system axons. Toxicol Appl Pharmacol. 1999; 161(1): 50-8 PubMed Abstract | Publisher Full Text

11. Gibbs $\mathrm{KL}$, Kalmar $\mathrm{B}$, Sleigh JN, et al:: In vivo imaging of axonal transport in murine motor and sensory neurons. J Neurosci Methods. 2016; 257: 26-33. PubMed Abstract | Publisher Full Text | Free Full Text

12. $\mathrm{F}$ Takihara $\mathrm{Y}$, Inatani $\mathrm{M}$, Eto $\mathrm{K}$, et al:: In vivo imaging of axonal transport of mitochondria in the diseased and aged mammalian CNS. Proc Natl Acad SC U S A. 2015; 112(33): 10515-20.

PubMed Abstract | Publisher Full Text | Free Full Text | F1000 Recommendation

13. Lewis TL Jr, Turi GF, Kwon SK, et al:: Progressive Decrease of Mitochondrial Motility during Maturation of Cortical Axons In Vitro and In Vivo. Curr Biol. 2016; 26(19): 2602-8. PubMed Abstract | Publisher Full Text | Free Full Text

14. Smit-Rigter L, Rajendran R, Silva CA, et al:: Mitochondrial Dynamics in Visual Cortex Are Limited In Vivo and Not Affected by Axonal Structural Plasticity. Curr Biol. 2016; 26(19): 2609-16.

PubMed Abstract | Publisher Full Text

15. Kiryu-Seo S, Ohno N, Kidd GJ, et al.: Demyelination increases axonal stationary mitochondrial size and the speed of axonal mitochondrial transport.

J Neurosci. 2010; 30(19): 6658-66.

PubMed Abstract | Publisher Full Text | Free Full Text 
16. F Ohno N, Kidd GJ, Mahad D, et al.: Myelination and axonal electrical activity modulate the distribution and motility of mitochondria at CNS nodes of Ranvier. J Neurosci. 2011; 31(20): 7249-58. PubMed Abstract | Publisher Full Text | Free Full Text | F1000 Recommendation

17. F Edgar JM, McLaughlin M, Yool D, et al:: Oligodendroglial modulation of fast axonal transport in a mouse model of hereditary spastic paraplegia. $J$ Cell Biol. 2004; 166(1): 121-31.

PubMed Abstract | Publisher Full Text | Free Full Text | F1000 Recommendation

18. Roux S, Saint Cloment C, Curie T, et al.: Brain-derived neurotrophic factor facilitates in vivo internalization of tetanus neurotoxin C-terminal fragment fusion proteins in mature mouse motor nerve terminals. Eur J Neurosci. 2006; 24(6): 1546-54.

PubMed Abstract | Publisher Full Text

19. Ji S, Jaffrey SR: Intra-axonal translation of SMAD1/5/8 mediates retrograde regulation of trigeminal ganglia subtype specification. Neuron. 2012; 74(1): 95-107.

PubMed Abstract | Publisher Full Text | Free Full Text

20. Sajic M, Mastrolia V, Lee CY, et al.: Impulse conduction increases mitochondrial transport in adult mammalian peripheral nerves in vivo. PLOS Biol. 2013; 11(12): e1001754.

PubMed Abstract | Publisher Full Text | Free Full Text

21. Wang T, Martin S, Nguyen TH, et al:: Flux of signalling endosomes undergoing axonal retrograde transport is encoded by presynaptic activity and TrkB. Nat Commun. 2016; 7: 12976 .

PubMed Abstract | Publisher Full Text

22. F Macaskill AF, Rinholm JE, Twelvetrees AE, et al.: Miro1 is a calcium sensor for glutamate receptor-dependent localization of mitochondria at synapses. Neuron. 2009; 61(4): 541-55.

PubMed Abstract | Publisher Full Text | Free Full Text | F1000 Recommendation

23. F Wang T, Martin S, Papadopulos A, et al:: Control of autophagosome axona retrograde flux by presynaptic activity unveiled using botulinum neurotoxin type a. J Neurosci. 2015; 35(15): 6179-94.

PubMed Abstract | Publisher Full Text | Free Full Text | F1000 Recommendation

24. Wiese S, Herrmann T, Drepper C, et al.: Isolation and enrichment of embryonic mouse motoneurons from the lumbar spinal cord of individual mouse embryos. Nat Protoc. 2010; 5(1): 31-8. PubMed Abstract | Publisher Full Text

25. Kaech S, Banker G: Culturing hippocampal neurons. Nat Protoc. 2006; 1(5) 2406-15

PubMed Abstract | Publisher Full Text

26. Hu BY, Weick JP, Yu J, et al:: Neural differentiation of human induced pluripotent stem cells follows developmental principles but with variable potency. Proc Natl Acad Sci U S A. 2010; 107(9): 4335-40.

PubMed Abstract | Publisher Full Text | Free Full Text

27. Schwarz TL: Mitochondrial trafficking in neurons. Cold Spring Harb Perspect Biol. 2013; 5(6): pii: a011304

PubMed Abstract | Publisher Full Text | Free Full Text

28. Misgeld T, Kerschensteiner M: In vivo imaging of the diseased nervous system. Nat Rev Neurosci. 2006; 7(6): 449-63.

PubMed Abstract | Publisher Full Text

29. Lichtman JW, Fraser SE: The neuronal naturalist: watching neurons in their native habitat. Nat Neurosci. 2001; 4(Suppl): 1215-20.

PubMed Abstract | Publisher Full Text

30. Plucinska G, Misgeld T: Imaging of neuronal mitochondria in situ. Curr Opin Neurobiol. 2016; 39: 152-63.

PubMed Abstract | Publisher Full Tex

31. Sleigh J, Sattelle D: C. elegans models of neuromuscular diseases expedite translational research. Transl Neurosci. 2010; 1(3): 214-227.

Publisher Full Text

32. Grice SJ, Sleigh JN, Liu JL, et al.: Invertebrate models of spinal muscular atrophy: insights into mechanisms and potential therapeutics. Bioessays. 2011; 33(12): 956-65.

PubMed Abstract | Publisher Full Text

33. Moloney A, Sattelle DB, Lomas DA, et al:: Alzheimer's disease: insights from Drosophila melanogaster models. Trends Biochem Sci. 2010; 35(4): 228-35. PubMed Abstract | Publisher Full Text | Free Full Text

34. Grice SJ, Sleigh JN, Motley WW, et al:: Dominant, toxic gain-of-function mutations in gars lead to non-cell autonomous neuropathology. Hum $\mathrm{Mol}$ Genet. 2015; 24(15): 4397-406.

PubMed Abstract | Publisher Full Text | Free Full Text

35. Alami NH, Smith RB, Carrasco MA, et al: Axonal transport of TDP-43 mRNA granules is impaired by ALS-causing mutations. Neuron. 2014; 81(3): 536-43. PubMed Abstract | Publisher Full Text | Free Full Text

36. Devireddy S, Liu A, Lampe T, et al.: The Organization of Mitochondrial Quality Control and Life Cycle in the Nervous System In Vivo in the Absence of PINK1. J Neurosci. 2015; 35(25): 9391-401.

PubMed Abstract | Publisher Full Text | Free Full Text

37. Janssens K, Goethals S, Atkinson D, et al.: Human Rab7 mutation mimics features of Charcot-Marie-Tooth neuropathy type 2B in Drosophila. Neurobiol Dis. 2014; 65: 211-9.

PubMed Abstract | Publisher Full Text

38. Morsci NS, Hall DH, Driscoll M, et al.: Age-Related Phasic Patterns of
Mitochondrial Maintenance in Adult Caenorhabditis elegans Neurons. J Neurosci. 2016; 36(4): 1373-85.

PubMed Abstract | Publisher Full Text | Free Full Text

39. Weiss KR, Littleton JT: Characterization of axonal transport defects in Drosophila Huntingtin mutants. J Neurogenet. 2016; 30(3-4): 212-21. PubMed Abstract | Publisher Full Text

40. F Baldwin KR, Godena VK, Hewitt VL, et al: Axonal transport defects are a common phenotype in Drosophila models of ALS. Hum Mol Genet. 2016; 25(12): 2378-92.

PubMed Abstract | Publisher Full Text | Free Full Text | F1000 Recommendation

41. F Pilling AD, Horiuchi D, Lively CM, et al:: Kinesin-1 and Dynein are the primary motors for fast transport of mitochondria in Drosophila motor axons. Mol Biol Cell. 2006; 17(4): 2057-68.

PubMed Abstract | Publisher Full Text | Free Full Text | F1000 Recommendation

42. Kuznicki ML, Gunawardena S: In vivo visualization of synaptic vesicles within Drosophila larval segmental axons. J Vis Exp. 2010; (44): pii: 2151. PubMed Abstract | Publisher Full Text | Free Full Text

43. $\mathrm{F}$ Mondal $\mathrm{S}$, Ahlawat $\mathrm{S}$, Rau $\mathrm{K}$, et al.: Imaging in vivo neuronal transport in genetic model organisms using microfluidic devices. Traffic. 2011; 12(4): 372-85.

PubMed Abstract | Publisher Full Text | F1000 Recommendation

44. Mishra B, Ghannad-Rezaie M, Li J, et al:: Using microfluidics chips for live imaging and study of injury responses in Drosophila larvae. J Vis Exp. 2014; (84): e50998.

PubMed Abstract | Publisher Full Text | Free Full Text

45. Vagnoni A, Hoffmann PC, Bullock SL: Reducing Lissencephaly-1 levels augments mitochondrial transport and has a protective effect in adult Drosophila neurons. J Cell Sci. 2016; 129(1): 178-90. PubMed Abstract | Publisher Full Text | Free Full Text

46. Vagnoni A, Bullock SL: A simple method for imaging axonal transport in aging neurons using the adult Drosophila wing. Nat Protoc. 2016; 11(9): 1711-23. PubMed Abstract | Publisher Full Text | Free Full Text

47. Nakamura M, Baldwin D, Hannaford S, et al.: Defective proboscis extension response (DPR), a member of the Ig superfamily required for the gustatory response to salt. J Neurosci. 2002; 22(9): 3463-72. PubMed Abstract

48. Palka J, Lawrence PA, Hart HS: Neural projection patterns from homeotic tissue of Drosophila studied in bithorax mutants and mosaics. Dev Biol. 1979; 69(2): $549-75$.

PubMed Abstract| Publisher Full Text

49. F Fang $Y$, Soares L, Teng $X$, et al:: A novel Drosophila model of nerve injury reveals an essential role of Nmnat in maintaining axonal integrity. Curr Biol. 2012; 22(7): 590-5.

PubMed Abstract | Publisher Full Text | Free Full Text | F1000 Recommendation

50. Fang $Y$, Soares L, Bonini NM: Design and implementation of in vivo imaging of neural injury responses in the adult Drosophila wing. Nat Protoc. 2013; 8(4): 810-9.

PubMed Abstract | Publisher Full Text | Free Full Text

51. Brosamle $\mathrm{C}$, Halpern ME: Characterization of myelination in the developing zebrafish. Glia. 2002; 39(1): 47-57.

PubMed Abstract | Publisher Full Text

52. Plucińska G, Paquet D, Hruscha A, et al:: In vivo imaging of disease-related mitochondrial dynamics in a vertebrate model system. J Neurosci. 2012; 32(46): 16203-12.

PubMed Abstract | Publisher Full Text

53. O'Donnell KC, Vargas ME, Sagasti A: WIdS and PGC-1 $\alpha$ regulate mitochondrial transport and oxidation state after axonal injury. J Neurosci. 2013; 33(37): 14778-90.

PubMed Abstract | Publisher Full Text | Free Full Text

54. Ponomareva OY, Holmen IC, Sperry AJ, et al:: Calsyntenin-1 regulates axon branching and endosomal trafficking during sensory neuron development in vivo. $J$ Neurosci. 2014; 34(28): 9235-48.

PubMed Abstract | Publisher Full Text | Free Full Text

55. Ponomareva OY, Eliceiri KW, Halloran MC: Charcot-Marie-Tooth $\mathbf{2 b}$ associated Rab7 mutations cause axon growth and guidance defects during vertebrate sensory neuron development. Neural Dev. 2016;11: 2

PubMed Abstract | Publisher Full Text | Free Full Text

56. Drerup CM, Nechiporuk AV: JNK-interacting protein 3 mediates the retrograde transport of activated c-Jun N-terminal kinase and lysosomes. PLOS Genet 2013; 9(2): e1003303.

PubMed Abstract | Publisher Full Text | Free Full Text

57. Drerup $\mathrm{CM}$, Nechiporuk $\mathrm{AV}$ : In vivo analysis of axonal transport in zebrafish Methods Cell Biol. 2016; 131: 311-29.

PubMed Abstract | Publisher Full Tex

58. Auer TO, Xiao T, Bercier V, et al:: Deletion of a kinesin I motor unmasks a mechanism of homeostatic branching control by neurotrophin-3. eLife. 2015; 4 e05061.

PubMed Abstract | Publisher Full Text | Free Full Text

59. Bergamin G, Cieri D, Vazza G, et al:: Zebrafish Tg(hb9:MTS-Kaede): a new in vivo tool for studying the axonal movement of mitochondria. Biochim Biophys Acta. 2016; 1860(6): 1247-55.

PubMed Abstract | Publisher Full Text 
60. Dukes AA, Bai Q, van Laar VS, et al:: Live imaging of mitochondrial dynamics in CNS dopaminergic neurons in vivo demonstrates early reversal of mitochondrial transport following MPP+ exposure. Neurobiol Dis. 2016; 95 238-49.

PubMed Abstract | Publisher Full Text | Free Full Text

61. F Kerschensteiner M, Schwab ME, Lichtman JW, et al.: In vivo imaging of axonal degeneration and regeneration in the injured spinal cord. Nat Med. 2005; 11(5): 572-7.

PubMed Abstract | Publisher Full Text | F1000 Recommendation

62. Cordeiro MF, Guo L, Luong V, et al:: Real-time imaging of single nerve cell apoptosis in retinal neurodegeneration. Proc Natl Acad Sci U S A. 2004; 101(36): 13352-6.

PubMed Abstract | Publisher Full Text | Free Full Text

63. $\mathrm{F}$ Stosiek $\mathrm{C}$, Garaschuk $\mathrm{O}$, Holthoff $\mathrm{K}$, et al: In vivo two-photon calcium maging of neuronal networks. Proc Natl Acad Sci U S A. 2003; 100(12): 7319-24. PubMed Abstract | Publisher Full Text | Free Full Text | F1000 Recommendation

64. F Grutzendler J, Kasthuri N, Gan WB: Long-term dendritic spine stability in the adult cortex. Nature. 2002; 420(6917): 812-6.

PubMed Abstract | Publisher Full Text | F1000 Recommendation

65. Abe T, Fujimori T: Reporter mouse lines for fluorescence imaging. Dev Growth Differ. 2013; 55(4): 390-405.

PubMed Abstract | Publisher Full Text

66. Misgeld T, Kerschensteiner M, Bareyre FM, et al.: Imaging axonal transport of mitochondria in vivo. Nat Methods. 2007; 4(7): 559-61.

PubMed Abstract | Publisher Full Text

67. F Bilsland LG, Sahai E, Kelly G, et al:: Deficits in axonal transport precede ALS symptoms in vivo. Proc Natl Acad Sci U S A. 2010; 107(47): 20523-8. PubMed Abstract | Publisher Full Text | Free Full Text | F1000 Recommendation

68. F Magrané J, Cortez C, Gan WB, et al:: Abnormal mitochondrial transport and morphology are common pathological denominators in SOD1 and TDP43 ALS mouse models. Hum Mol Genet. 2014; 23(6): 1413-24. PubMed Abstract | Publisher Full Text | Free Full Text | F1000 Recommendation

69. F Bercsenyi K, Schmieg N, Bryson JB, et al:: Tetanus toxin entry. Nidogens are therapeutic targets for the prevention of tetanus. Science. 2014; 346(6213): $1118-23$.

PubMed Abstract | Publisher Full Text | F1000 Recommendation

70. Malik B, Nirmalananthan N, Bilsland LG, et al:: Absence of disturbed axona transport in spinal and bulbar muscular atrophy. Hum Mol Genet. 2011; 20(9): 1776-86.

PubMed Abstract | Publisher Full Text | Free Full Text

71. Sleigh J, Schiavo G: Older but not slower: Aging does not alter axonal transport dynamics of signalling endosomes in vivo. Matters. 2016. Publisher Full Text

72. F Bolea I, Gan W, Manfedi G, et al.: Imaging of mitochondrial dynamics in motor and sensory axons of living mice. Meth Enzymol. 2014; 547: 97-110. PubMed Abstract | Publisher Full Text | F1000 Recommendation

73. Misgeld T, Nikic I, Kerschensteiner M: In vivo imaging of single axons in the mouse spinal cord. Nat Protoc. 2007; 2(2): 263-8. PubMed Abstract | Publisher Full Text

74. Davalos D, Lee JK, Smith WB, et al:: Stable in vivo imaging of densely populated glia, axons and blood vessels in the mouse spinal cord using two-photon microscopy. J Neurosci Methods. 2008; 169(1): 1-7. PubMed Abstract | Publisher Full Text | Free Full Text

75. Farrar MJ, Bernstein IM, Schlafer $\mathrm{DH}$, et al:: Chronic in vivo imaging in the mouse spinal cord using an implanted chamber. Nat Methods. 2012; 9(3): 297-302. PubMed Abstract | Publisher Full Text | Free Full Text

76. Romanelli E, Sorbara CD, Nikić $I$, et al.: Cellular, subcellular and functional in vivo labeling of the spinal cord using vital dyes. Nat Protoc. 2013; 8(3): 481-90. PubMed Abstract | Publisher Full Text

77. Sorbara CD, Wagner NE, Ladwig A, et al:: Pervasive axonal transport deficits in multiple sclerosis models. Neuron. 2014; 84(6): 1183-90. PubMed Abstract | Publisher Full Text

78. Shidara $Y$, Hollenbeck PJ: Defects in mitochondrial axonal transport and membrane potential without increased reactive oxygen species production in a Drosophila model of Friedreich ataxia. J Neurosci. 2010; 30(34):
11369-78

PubMed Abstract | Publisher Full Text | Free Full Text

79. $\mathrm{F}$ Higashijima S, Hotta $\mathrm{Y}$, Okamoto $\mathrm{H}$ : Visualization of cranial motor neurons n live transgenic zebrafish expressing green fluorescent protein under the control of the islet-1 promoter/enhancer. J Neurosci. 2000; 20(1): 206-18. PubMed Abstract | F1000 Recommendation

80. Kawakami R, Sawada K, Kusama $\mathrm{Y}$, et al.: In vivo two-photon imaging of mouse hippocampal neurons in dentate gyrus using a light source based on a high-peak power gain-switched laser diode. Biomed Opt Express. 2015; 6(3) 891-901.

PubMed Abstract | Publisher Full Text | Free Full Text

81. Brown R, Dissanayake KN, Skehel PA, et al:: Endomicroscopy and electromyography of neuromuscular junctions in situ. Ann Clin Transl Neurol. 2014; 1(11): 867-83.

PubMed Abstract | Publisher Full Text | Free Full Text

82. Pan YA, Misgeld T, Lichtman JW, et al.: Effects of neurotoxic and neuroprotective agents on peripheral nerve regeneration assayed by timelapse imaging in vivo. J Neurosci. 2003; 23(36): 11479-88.

PubMed Abstract

83. Andermann ML, Gilfoy NB, Goldey GJ, et al.: Chronic cellular imaging of entire cortical columns in awake mice using microprisms. Neuron. 2013; 80(4): 900-13.

PubMed Abstract | Publisher Full Text | Free Full Text

84. Koch JC, Knöferle J, Tönges $\mathrm{L}$, et al.: Imaging of rat optic nerve axons in vivo. Nat Protoc. 2011; 6(12): 1887-96. PubMed Abstract | Publisher Full Text

85. Mohan R, Tosolini AP, Morris R: Targeting the motor end plates in the mouse hindlimb gives access to a greater number of spinal cord motor neurons: an approach to maximize retrograde transport. Neuroscience. 2014; 274: 318-30. PubMed Abstract | Publisher Full Text

86. Tosolini AP, Morris R: Targeting Motor End Plates for Delivery of Adenoviruses: An Approach to Maximize Uptake and Transduction of Spinal Cord Motor Neurons. Sci Rep. 2016; 6: 33058.

PubMed Abstract | Publisher Full Text | Free Full Tex

87. Kim JK, Lee WM, Kim P, et al:: Fabrication and operation of GRIN probes for in vivo fluorescence cellular imaging of internal organs in small animals. Nat Protoc. 2012; 7(8): 1456-69.

PubMed Abstract | Publisher Full Text | Free Full Text

88. Hamzeh $\mathrm{H}$, Lefort $\mathrm{C}$, Pain $\mathrm{F}$, et al: Optimization and characterization of nonlinear excitation and collection through a gradient-index lens for highresolution nonlinear endomicroscopy. Opt Lett. 2015; 40(5): 808-11. PubMed Abstract | Publisher Full Text

89. Kim J, Choi IY, Michaelis ML, et al.: Quantitative in vivo measurement of early axonal transport deficits in a triple transgenic mouse model of Alzheimer's disease using manganese-enhanced MRI. Neuroimage. 2011; 56(3): 1286-92. PubMed Abstract | Publisher Full Text | Free Full Text

90. Li W, Hoffman PN, Stirling W, et al: : Axonal transport of human alpha-synuclein slows with aging but is not affected by familial Parkinson's disease-linked mutations. J Neurochem. 2004; 88(2): 401-10. PubMed Abstract | Publisher Full Text

91. F DiMauro S, Schon EA, Carelli V, et al.: The clinical maze of mitochondrial neurology. Nat Rev Neurol. 2013; 9(8): 429-44. PubMed Abstract | Publisher Full Text | Free Full Text | F1000 Recommendation

92. Marinkovic $\mathrm{P}$, Reuter MS, Brill MS, et al:: Axonal transport deficits and degeneration can evolve independently in mouse models of amyotrophic lateral sclerosis. Proc Natl Acad Sci U S A. 2012; 109(11): 4296-301. PubMed Abstract | Publisher Full Text | Free Full Text

93. Nicovich PR, Zhou FQ: Acquisition frame rate affects microtubule plus-end tracking analysis. Nat Methods. 2014; 11(3): 219-20. PubMed Abstract | Publisher Full Text

94. Danuser G: Reply to "Acquisition frame rate affects microtubule plus-end tracking analysis". Nat Methods. 2014; 11(3): 220. PubMed Abstract | Publisher Full Text

95. Yoon YJ, Wu B, Buxbaum AR, et al:: Glutamate-induced RNA localization and translation in neurons. Proc Natl Acad Sci U S A. 2016; 113(44): E6877-E6886. PubMed Abstract | Publisher Full Text | Free Full Text 


\section{Open Peer Review}

\section{Current Peer Review Status:}

\section{Editorial Note on the Review Process}

Faculty Reviews are review articles written by the prestigious Members of Faculty Opinions. The articles are commissioned and peer reviewed before publication to ensure that the final, published version is comprehensive and accessible. The reviewers who approved the final version are listed with their names and affiliations.

\section{The reviewers who approved this article are:}

\section{Version 1}

\section{Bettina Winckler}

Department of Cell Biology, University of Virginia, Charlottesville, VA, USA

Competing Interests: No competing interests were disclosed.

\section{Michael Sendtner}

Institute of Clinical Neurobiology, University of Würzburg, Würzburg, Germany

Competing Interests: No competing interests were disclosed.

\section{William C. Mobley}

Department of Neurosciences, University of California, San Diego, La Jolla, CA, USA

Competing Interests: No competing interests were disclosed.

The benefits of publishing with F1000Research:

- Your article is published within days, with no editorial bias

- You can publish traditional articles, null/negative results, case reports, data notes and more

- The peer review process is transparent and collaborative

- Your article is indexed in PubMed after passing peer review

- Dedicated customer support at every stage

For pre-submission enquiries, contact research@f1000.com 